\title{
Epidemiological data on Staphylococcus aureus strains producing synergohymenotropic toxins
}

\author{
G. PREVOST*, P. COUPPIE†, P. PREVOST $\ddagger$ S. GAYET\&, P. PETIAU†, B. CRIBIER $\dagger$, H. MONTEIL* \\ and Y. PIEMONT* \\ * Institut de Bactériologie de la Faculté de Médecine de Strasbourg, 3, rue Koeberlé, 67000 Strasbourg, †Clinique \\ Dermatologique des Hôpitaux Universitaires de Strasbourg, 1, place de l'Hôpital, 67000 Strasbourg, + Clinique \\ Chirurgicale A des Hôpitaux Universitaires de Strasbourg, 1, place de I'Hôpital, 67000 Strasbourg, \$Institut \\ d'Hygiène de la Faculté de Médecine de Strasbourg, 4, rue Kirschleger, 67000 Strasbourg. France
}

\begin{abstract}
Summary. DNA hybridisation of 309 consecutive Staphylococcus aureus clinical isolates with oligonucleotide probes specific for genes encoding Panton-Valentine leucocidin (luk-PV) and $\gamma$-haemolysin $(h l g)$ revealed that $99 \%$ of randomly selected strains carried the $h l g$ locus whereas only $2 \%$ harboured the luk-PV as well as the $h l g$ loci. Only $1 \%$ of the strains did not possess either gene. In a clinical prospective study of independent $S$. aureus strains, 58 Panton-Valentine leucocidin (PVL)-producing isolates were shown to be responsible for primary skin infections, mainly furuncles $(86 \%)$. Phage susceptibility patterns and pulsed field gel electrophoresis (PFGE) profiles of DNA were shown to be polymorphic epidemiological markers of PVL-producing strains. In eight patients with recurrent furuncles, the PVL-producing strains isolated either from furuncles or from the anterior nares were considered to be identical in each based upon phage sensitivity profiles or PFGE patterns.
\end{abstract}

\section{Introduction}

Among the toxins produced by Staphylococcus aureus, Panton-Valentine leucocidin (PVL) ${ }^{1}$ and $\gamma$ haemolysin ${ }^{2,3}$ are bi-component toxins which have been demonstrated recently to be members of a single family of toxins-the synergohymenotropic toxins. ${ }^{4,5}$

The name Panton-Valentine leucocidin (PVL) was definitively given by Gladstone and Van Heyningen ${ }^{6}$ because of the exclusive biological activity of this toxin, formerly discovered by Panton and Valentine, ${ }^{\text {? }}$ upon human and rabbit polymorphonuclear cells. PVL was purified ${ }^{8,9}$ from the highly leucotoxic culture supernate of strain V8 (ATCC 49775). The biological activity of PVL resulted from the synergic action of two separate exoproteins, the $\mathrm{S}(32 \mathrm{kDa})$ and $\mathrm{F}$ $(38 \mathrm{kDa})$ components. These two proteins are encoded by two co-transcribed genes, $l u k \mathrm{~S}-\mathrm{PV}$ and $l u k \mathrm{~F}-\mathrm{PV},{ }^{4}$ respectively. LukS-PV and LukF-PV are part of the first structural subgroup of the family of toxins.

The primary structure of these proteins has $c .72 \%$ identity to that of the components of each of the toxins belonging to a second two-component structural subgroup of toxins of $S$. aureus. The latter subgroup

Received 26 July 1994; accepted 19 Sept. 1994

$\|$ Correspondence should be sent to Professor Y. Piemont. includes three closely related synergohymenotropic toxins ( $>96 \%$ identity within this subgroup) referred to as "leucocidin R", 5,10 "leucocidin from a methicillin-resistant $S$. aureus", ${ }^{11-14}$ and $\gamma$ haemolysin. ${ }^{15,16}$ The latter subgroup of toxins, called the $\gamma$-haemolysin subgroup, is encoded by a locus consisting of three open-reading frames: one of them $(h l g \mathrm{~A})$ is separately transcribed, and is located $570 \mathrm{bp}$ upstream from the other two ( $h l g \mathrm{C}$ and $h l g \mathrm{~B})$ which are co-transcribed. The genes $h l g \mathrm{~A}$ and $h l g \mathrm{C}$ are structurally and functionally close to lukS-PV, whereas $h l g \mathrm{~B}$ is structurally and functionally close to lukF-PV.4, 16 The genes $h l g \mathrm{C}$ and $h l g \mathrm{~B}$ are, like $l u k \mathrm{~S}-\mathrm{PV}$ and $l u k \mathrm{~F}-\mathrm{PV}$, tandemly transcribed, but there is no $h l g \mathrm{~A}-$ like open reading frame in the vicinity of the two PVL-encoding genes.

Although the PVL and $\gamma$-haemolysin group are closely related, it has to be emphasised that PVL is strongly cytolytic by the combined action of the $\mathrm{S}$ and $\mathrm{F}$ components upon human and rabbit polymorphonuclear cells (PMNs), monocytes and macrophages but not upon erythrocytes, whereas members of the $\gamma$-haemolysin subgroup are leucotoxic and also haemolytic by the association of $\mathrm{HlgA}$ or $\mathrm{HlgC}$ with HlgB.

Preliminary studies had shown that PVL-producing strains might be associated with cutaneous infec- 
tions. ${ }^{8,17,18}$ The aim of this study was to determine the possible epidemiological association of $\gamma$-haemolysinand PVL-producing strains with clinical syndromes.

\section{Materials and methods}

\section{Bacterial strains}

$S$. aureus isolates were identified as gram-positive cocci producing free coagulase, catalase and acetoin, but devoid of $\beta$-galactosidase activity. The reference $S$. aureus strains were: PVL-producing strain V8 (ATCC 49775) kindly provided by Dr S. Thornley (Wellcome Laboratories, London), and $\gamma$-haemolysin-producing strains Smith $5 \mathrm{R}$ and P83 generously given by N. El Solh (Institut Pasteur, Paris), and N. L. Norcross (Cornell University, Ithaca, NY, USA), respectively.

A preliminary study of the distribution of the genes encoding synergohymenotropic toxins included 309 consecutive isolates of $S$. aureus obtained from the bacteriology laboratory of the Strasbourg University General Hospital. The origin of the isolates is detailed in table I.

In a prospective study, the phenotypic expression of PVL was measured in 346 S. aureus strains (table II), 69 of which originated from blood cultures, 31 from asymptomatic nasal carriers and 246 from various forms of cutaneous infection.

\section{Phenotypic detection of PVL-producing strains}

The detection of PVL-producing strains was based on an immunoprecipitation assay as described earlier. ${ }^{8}$ Briefly, bacteria were grown in a CCY modified medium by the sac culture method. ${ }^{8}$ One colony of $S$. aureus was suspended in $20 \mathrm{ml}$ of $0.02 \mathrm{M}$ sodium phosphate buffer, $0 \cdot 15 \mathrm{M} \mathrm{NaCl}, \mathrm{pH} 7 \cdot 5$. This suspension was transferred to a 2-L Erlenmeyer flask containing a sterile dialysis bag filled with $120 \mathrm{ml}$ of modified CCY medium. The cultures were incubated

Table I. Distribution of genes encoding synergohymenotropic toxins among 309 consecutive isolates of $S$. aureus

\begin{tabular}{lccc}
\hline Specimen & $\begin{array}{c}\text { Number } \\
\text { of isolates }\end{array}$ & $\begin{array}{c}\text { Number of } \\
l u k \text {-PV-positive } \\
\text { isolates* }\end{array}$ & $\begin{array}{c}\text { Number of } \\
h l g \text {-positive } \\
\text { isolates }\end{array}$ \\
\hline Blood cultures & 20 & 0 & 20 \\
Bronchoalveolar fluids & 15 & 0 & 15 \\
Tracheal aspirations & 106 & 2 & 106 \\
$\quad$ and sputa & 89 & 3 & 89 \\
Superficial lesions & 18 & 0 & 18 \\
Stools & 12 & 0 & 12 \\
Catheters & 40 & 0 & 39 \\
Urines & 9 & 0 & 8 \\
Others & 309 & 5 & 307 \\
Total & & &
\end{tabular}

*All these isolates hybridised with the two probes designed for the luk-PV locus.

†All these isolates hybridised with the three probes designed for the hlg locus. at $37^{\circ} \mathrm{C}$ for $18 \mathrm{~h}$ with vigorous shaking. The double immunoprecipitation test was performed in an agarose $0.6 \% \mathrm{w} / \mathrm{v}$ gel (Seakem-GTG, FMC products) prepared in phosphate-buffered saline (PBS; $20 \mathrm{~mm} \mathrm{Na-}$ $\mathrm{K}_{2}$ phosphate buffer, $150 \mathrm{~mm} \mathrm{NaCl}, \mathrm{pH} \mathrm{7.5)}$ with $\mathrm{NaN}_{3} 0 \cdot 5 \% \mathrm{w} / \mathrm{v}, \mathrm{pH} 7 \cdot 5$. Wells (4 mm diam.) were cut in the gel, forming a crown of six wells with a central seventh well. $\mathrm{F}$ or $\mathrm{S}$ affinity-purified antibodies were added into the central well, whereas peripheral wells were charged with $35 \mu \mathrm{l}$ of staphylococcal culture supernate or $35 \mu \mathrm{l}$ of purified S or F. After incubation for $18 \mathrm{~h}$ at $4^{\circ} \mathrm{C}$, the presence of immunoprecipitation lines was recorded.

\section{DNA methods}

Restriction endonucleases and DNA modifying enzymes were used as recommended by the manufacturers (Gibco-Bethesda Research Laboratories, and New England Biolabs). To determine the presence of PVL- or $\gamma$-haemolysin-encoding genes, DNA was prepared by the following procedure. Bacteria were grown overnight in $10 \mathrm{ml}$ of $2 \times \mathrm{TY}$ medium $^{19}$ and then pelleted by centrifugation at $5000 \mathrm{~g}$ for $5 \mathrm{~min}$ at $0^{\circ} \mathrm{C}$. After washing with $5 \mathrm{ml}$ of distilled water, bacteria were resuspended in $2 \mathrm{ml}$ of $0.05 \mathrm{M}$ Tris- $\mathrm{HCl}$ buffer sucrose $25 \% \mathrm{w} / \mathrm{v}, \mathrm{pH} 7 \cdot 5$, containing lysostaphin (Biozyme, New York) $200 \mu \mathrm{g} / \mathrm{ml}$, and lysozyme (Appligene Strasbourg, France) $250 \mu \mathrm{g} / \mathrm{ml}$. After treatment for $1 \mathrm{~h}$ at $37^{\circ} \mathrm{C}$, to the protoplast suspension was added $100 \mu \mathrm{l}$ of SDS $10 \% \mathrm{w} / \mathrm{v}$ and $110 \mu \mathrm{l}$ of $0.5 \mathrm{M}$ EDTA, $\mathrm{pH} 8.0$ and the mixture was heated for $10 \mathrm{~min}$ at $55^{\circ} \mathrm{C}$. Nucleic acids were extracted twice with $2 \mathrm{ml}$ of phenol:chloroform (1:1) and three times with diethylether before being precipitated with alcohol. After drying, nucleic acids were dissolved in $300 \mu \mathrm{l}$ of $10 \mathrm{~mm}$ Tris-HCl, $1 \mathrm{~mm}$ EDTA, pH $8 \cdot 0$, containing RNAase A (Sigma) $20 \mu \mathrm{g} / \mathrm{ml}$, and then stored at $-20^{\circ} \mathrm{C}$. The DNA fragments resulting from EcoRI restriction hydrolyses were electrophoresed on agarose gels and transferred on to Immobilon $\mathrm{P}$ membranes (Millipore, Molsheim, France). Southern blotting was performed as described previously ${ }^{20}$ with oligonucleotide probes specific for genes encoding each of the two components of the Panton-Valentine leucocidin and each of the three components of the $\gamma$-haemolysin group. The sequences for the probes were deduced from the sequence of the genes encoding the Panton-Valentine leucocidin and from the sequence of the genes encoding a member of the $\gamma$-haemolysins group, the leucocidin $\mathrm{R}$. The nucleotide sequences of these two toxins were deposited at the EMBL/GenBank Data library with the numbers $X$ 72700 and X 64389, respectively. Probes for genes encoding the $S$ and the $F$ components of PVL were 1500 5'-CCCCATTAGTACACAG-3' 1515 and 2386 5'-ATTCAACTTATGGTAAT-3' 2402, respectively. Probes for the three genes $(h l g \mathrm{~A}, h l g \mathrm{C}, h l g \mathrm{~B})$ encoding leucocidin R (or $\gamma$-haemolysin) were $8725^{\prime}$-AGCGAGTTTGAAATCACTTACGG-3' 894, 1076 5'- 
Table II. Distribution of PVL-producing S. aureus strains among clinical samples taken from cutaneous infections, septicaemias and asymptomatic nasal carriers

\begin{tabular}{lccc}
\hline Sample origin & $\begin{array}{c}\text { Number } \\
\text { of strains } \\
\text { tested }\end{array}$ & $\begin{array}{c}\text { Number of } \\
\text { PVL-positive } \\
\text { strains }\end{array}$ & $\begin{array}{c}\text { Number of } \\
\text { PVL-negative } \\
\text { strains }\end{array}$ \\
\hline Blood & 69 & 1 & 68 \\
Nose & 31 & 0 & 31 \\
Primary pyodermas & & & \\
$\quad$ Furunculosis & 43 & 37 & 6 \\
$\quad$ Abscess & 19 & 7 & 12 \\
$\quad$ Whitlow & 44 & 10 & 34 \\
Folliculitis & 19 & 1 & 18 \\
$\quad$ Impetigo contagiosa & 23 & 1 & 22 \\
$\quad$ Ecthyma & 16 & 0 & 16 \\
Secondary pyodermas & 82 & 1 & 81 \\
Total & 346 & 58 & 288 \\
& & & \\
\hline
\end{tabular}

TGTGACCATCTAAATAAC-3' 1059, and 1592 5'GGTGGTGACATCAGTATCTCT-3' 1612, respectively. The latter three probes were chosen in nucleotide sequences strictly conserved within the three genes encoding the three known $\gamma$-related haemolysins. Pre-hybridisation was performed for $2 \mathrm{~h}$ at $55^{\circ} \mathrm{C}$ in $6 \times$ SSPE, $5 \times$ Denhardt's solution, ${ }^{19}$ SDS $0.05 \% \mathrm{w} / \mathrm{v}$. Hybridisation was done at the same temperature for $14 \mathrm{~h}$ in the same buffer containing $1 \mathrm{pmol}$ of oligonucleotide, $5^{\prime}$-labelled with ${ }^{32} \mathrm{P}$ by $\mathrm{T} 4$ polynucleotide kinase. Membranes were then washed twice for $20 \mathrm{~min}$ at $45^{\circ} \mathrm{C}$ in $1 \times$ SSPE, SDS $0.05 \% \mathrm{w} / \mathrm{v}$ and dried before exposure to a Fuji X-ray film at $-70^{\circ} \mathrm{C}$ for $16 \mathrm{~h}$. To perform sequential hybridisations with various probes on the same membrane-immobilised DNA, dehybridisation was obtained by three 5-min washes in TE buffer at $90^{\circ} \mathrm{C}$. These membranes were then dried for $1 \mathrm{~h}$ at $80^{\circ} \mathrm{C}$ under vacuum. A pre-hybridisation step preceded each hybridisation with another oligonucleotide probe.

\section{Epidemiological markers and PVL-producing strains}

The polymorphism of PVL-producing staphylococci was studied in a cohort of 75 isolates. This investigation included the 58 PVL-producing independent isolates described in the prospective study (table II). Of the 58 patients from whom these strains were isolated, seven had several episodes of furuncles. An eighth epidemiologically related patient was also sampled: he belonged to the same family as one of the seven patients and was not included in the group of 58 . Several nasal and furuncle swabs were taken from these eight patients resulting in 24 PVL-producing isolates: seven were considered to be distinct, and the remaining 17 were linked epidemiologically to these seven strains.

\section{Phage typing}

Phage susceptibility patterns were determined with the international set of typing phages according to
Blair and Williams ${ }^{21}$ at routine test dilution (RTD) and at $100 \times$ RTD. Two samples were considered as having different phage types when they differed by at least two phage susceptibilities.

\section{Pulsed field gel electrophoresis}

For typing by pulsed field gel electrophoresis (PFGE), the DNA preparations, SmaI restriction endonuclease and electrophoretic conditions for PFGE on a transverse alternating field electrophoresis apparatus (GeneLine, Beckman) were as reported previously. ${ }^{22}$

\section{Results}

\section{Distribution of genes encoding synergohymenotropic toxins among hospital isolates of $S$. aureus}

In our preliminary study, the distribution of PVLand $\gamma$-haemolysin-encoding genes was examined among 309 consecutive hospital isolates of $S$. aureus. $E c o$ RI-restricted DNA of each isolate was successively hybridised with $l u k \mathrm{~S}-\mathrm{PV}-, \ln k \mathrm{~F}-\mathrm{PV}-, h l g \mathrm{~A}-, h l g \mathrm{C}$ - and $h l g \mathrm{~B}$-specific gene probes. The DNA from 307 isolates $(99 \cdot 3 \%)$ hybridised with the three probes specific for $h l g \mathrm{~A}, h l g \mathrm{C}$ and $h l g \mathrm{~B}$. The hybridised $E c o \mathrm{RI}$ restriction fragments always had the same apparent size ( $>$ $8.3 \mathrm{~kb}$ ) with $h l g \mathrm{~A}$ and $h l g \mathrm{C}$ probes and all had a size of $4.0 \mathrm{~kb}$ when detected with the $h l g \mathrm{~B}$ probe (fig. 1a and b). No apparent length variation of the detected DNA fragments was observed amongst the strains. No strain hybridised with only one or two of the three $\gamma$ haemolysin probes. Culture supernates of these 307 strains produced immunoprecipitation lines with affinity-purified PVL-antibodies. However, these lines failed to show complete identity with those obtained with purified LukS-PV or LukF-PV as antigens, because, as previously mentioned, ${ }^{8}$ PVL and $\gamma$ haemolysin share common sequences, and probably common epitopes.

DNA of only five strains $(1.6 \%)$ hybridised with the two luk-PV probes. The expression of PVL was verified in these five strains by immunoprecipitation with affinity-purified PVL-antibodies. The precipitation lines had complete identity with those obtained with purified $\mathrm{S}$ or $\mathrm{F}$ antigens. Among these five isolates, three originated from skin infections (two abscesses and one whitlow); two other isolates were obtained from sputa. One of these came from a 78year-old patient who developed pneumopathy after surgery of the hip, with no cutaneous infection. The second isolate originated from a long-term immunosuppressed 53-year-old woman, suffering from breast cancer and having bronchitis, but without any cutaneous lesion.

It has to be emphasised that, just like the reference S. aureus strain ATCC 49775 , the DNA of all the PVLproducing strains hybridised not only with $l u k \mathrm{~S}-\mathrm{PV}$ and $l u k$ F-PV probes, but also with $h l g \mathrm{~A}, h l g \mathrm{C}$ and $h l g \mathrm{~B}$ 


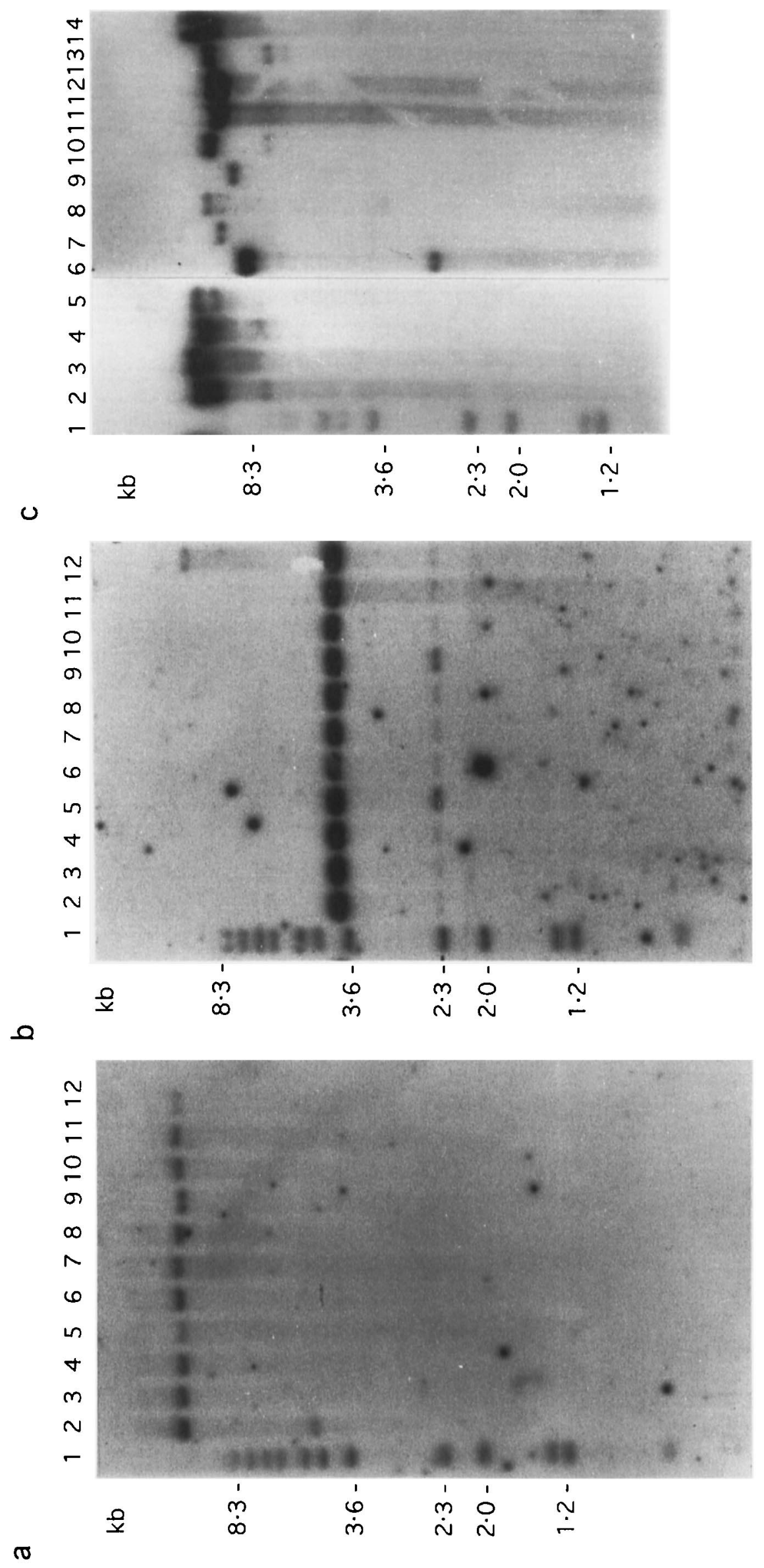

울웡용

实

递

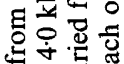

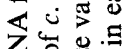

西

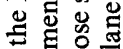

is

뭉

过

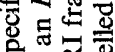

i

要的

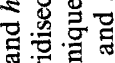

证

S

동

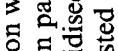

等

s

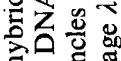
品

政

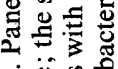

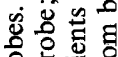

은을.

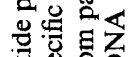

잉옹

政

옹

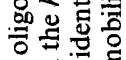

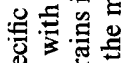

落

>

등

늘

을

然

s

豙

용

s

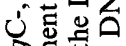

₹

i

急事

군원

क ㅎํ원

돌.

s

s. 군

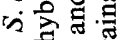

哣市

of 웅

흥.의

政

on:-

最.

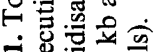


Table III. Distribution of phage types among 58 PVLproducing strains of $S$. aureus

\begin{tabular}{llc}
\hline Phage groups & \multicolumn{1}{c}{ Phage types } & $\begin{array}{c}\text { Number (\%) } \\
\text { of isolates }\end{array}$ \\
\hline NT & NT & $22(39)$ \\
II & $3 \mathrm{C} / 55$ & $17(29)$ \\
& $3 \mathrm{~A} / 3 \mathrm{C} / 55 / 71$ & $10(18)$ \\
III & $42 \mathrm{E} / 81$ & $1(1 \cdot 7)$ \\
& $47 / 54$ & $1(1 \cdot 7)$ \\
V & $54 / 75$ & $3(5 \cdot 1)$ \\
Miscellaneous & $94 / 96$ & $1(1 \cdot 7)$ \\
& $3 \mathrm{~A} / 3 \mathrm{C} / 47 / 54$ & $1(1 \cdot 7)$ \\
& $3 \mathrm{~A} / 3 \mathrm{C} / 42 \mathrm{E} / 47 / 54 / 81 / 95$ & $1(1 \cdot 7)$ \\
& $3 \mathrm{~A} / 3 \mathrm{C} / 55 / 71 / 6 / 47 / 75 / 81 / 94$ & $1(1 \cdot 7)$ \\
\hline
\end{tabular}

NT, non-typable.

probes. These hybridisations with $h l g$ genes occurred on EcoRI DNA fragments of the same size as those from isolates having only the locus for $\gamma$-haemolysin.

Finally, DNA of only two strains $(0.7 \%)$ deemed subsequently to be contaminants did not hybridise with any of the five probes. Culture supernates did not contain synergohymenotropic toxin nor did they contain leucotoxic activity. A 1 in 10 dilution of the culture supernates was unable to lyse $10^{5}$ human PMNs. By comparison, dilutions of culture supernate ranging from 1 in 300 to 1 in 3000 of $\gamma$-haemolysin- producing strains and of PVL-producing strains were able to lyse $10^{5}$ adsorbed human PMNs.

\section{Clinical association of PVL-producing S. aureus strains}

It appears that $99 \%$ of $S$. aureus isolates produce $\gamma$-haemolysin. Therefore, the clinical association between these strains and a clinical syndrome is not demonstrable. By contrast, the low frequency $(2 \%)$ of PVL-producing strains makes it possible to seek an association with a clinical syndrome on the basis of reports of its role in septicaemia ${ }^{1,12}$ and in some cutaneous infections..$^{8,17,18}$

In a prospective study with 346 distinct strains of $S$. aureus (table II), only one of 69 isolates from blood cultures produced PVL in the immunoprecipitation test. Similarly, no PVL-positive strain was isolated from the anteriors nares of 31 asymptomatic nasal carriers.

Fifty-eight PVL-producing strains were isolated from 246 cutaneous infections. Most of them ( 56 of 58) were associated with primary cutaneous infections. This result was significant when compared with strains isolated from secondary cutaneous infections $(\mathrm{p}<$ $0.05)$. The 58 PVL-producing isolates were distributed between furuncles (64\%), abscesses $(13 \%)$ and whitlows $(17 \%)$. Conversely, PVL-producing $S$. aureus strains were detected in $86 \%$ of the furuncles,

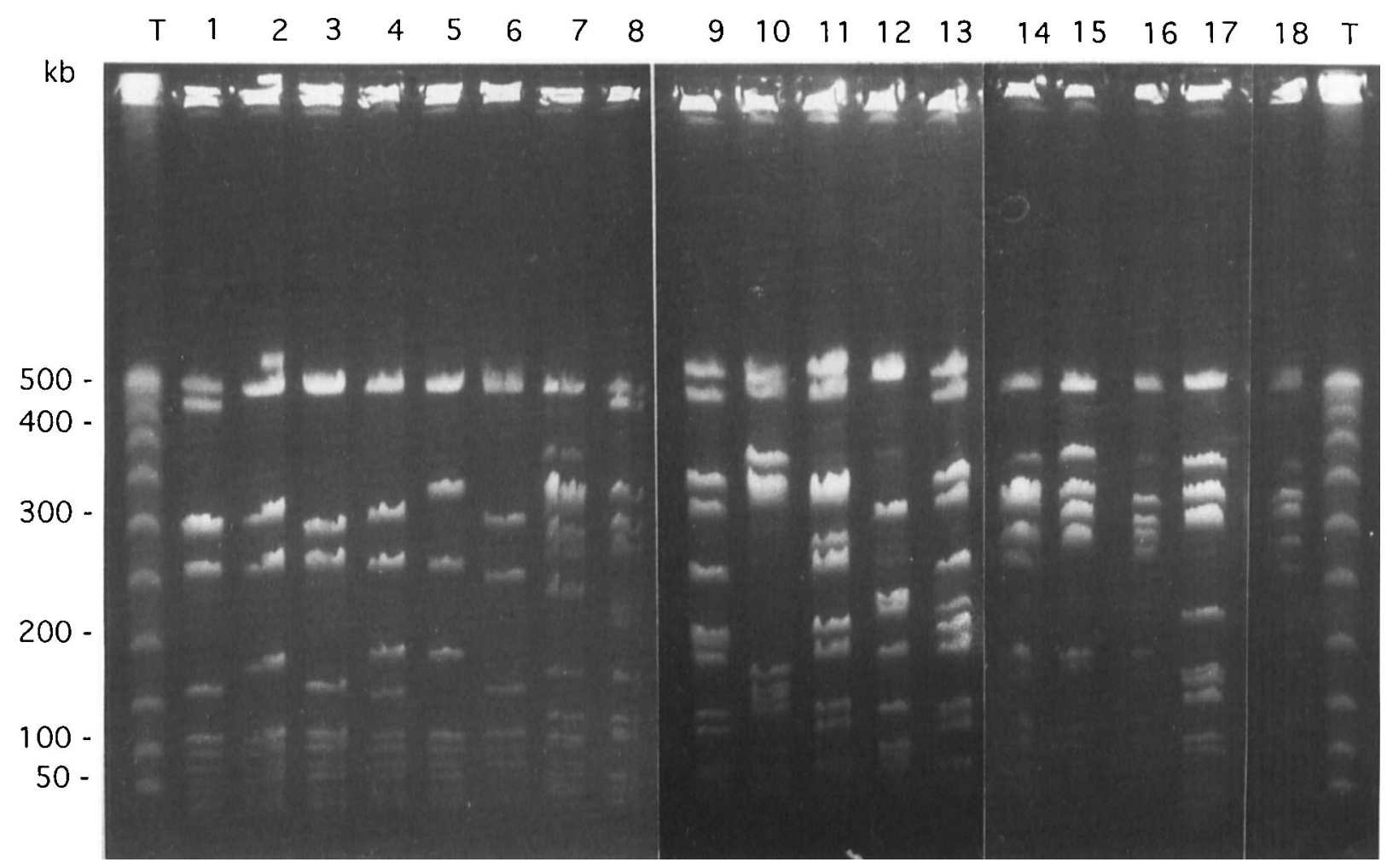

Fig. 2. DNA fingerprint analysis from 58 PVL-producing $S$. aureus strains by transverse alternating PFGE showing 18 different profiles. Chromosomal DNA was digested with $S m a$ I restriction endonuclease and the fragments were separated by PFGE. $\mathbf{M}_{\mathbf{r}}($ lane $\mathbf{T})$ are indicated in $\mathrm{kb}$, and were obtained from bacteriophage $\lambda$ concatemers (FMC products). The different fingerprints identified from the 58 strains are shown in lanes 1-18. 


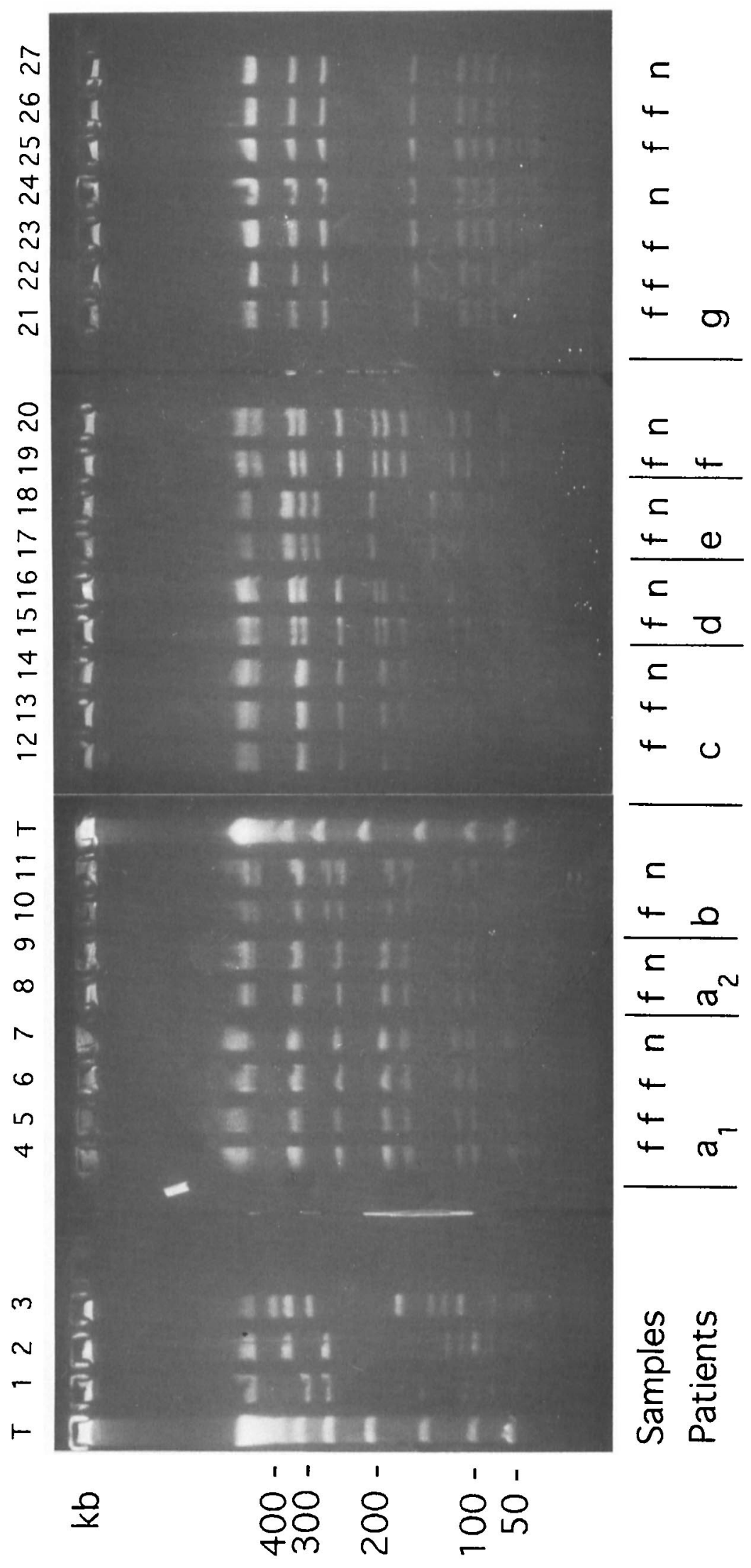

요요

㗉

政

政:

尊

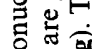

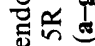

올.气

约

屯

赵

जी

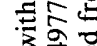

'0

总象

语

3 䨪

Z

可总的

纯芯

岁要

일 焉

记苋

덩

놀

要焉

훙

氙

表安

近苛

表范

를

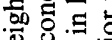

ह

인

뭉형

到.

30

引㐘

的氙泉

열

氜氙

응월뻔

分密焉

2

ธ를

号立恶

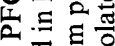

릉ㅇㅇㅇ

3 需

뭉

긍

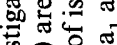

国政

㤩运

తृ

닝 넹

焉㟔

은

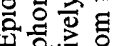


$37 \%$ of the abscesses and $23 \%$ of the whitlows. Whitlows were considered as primary infections since no other micro-organism was identified. In eight patients with recurrent furuncles, a PVL-producing strain was isolated on at least two occasions, and at least once from the anterior nares. Only one PVLpositive isolate out of 58 was found as a superinfection of a cutaneous lesion.

All 58 cutaneous PVL-producing isolates were further characterised to eliminate the possibility of outbreaks of cutaneous lesions due to a limited number of strains. This strategy was designed to strengthen the epidemiological link between primary cutaneous lesions and PVL-producing strains. Three epidemiological markers were used: phage susceptibility patterns, genetic toxinotyping and PFGE electrophoretic DNA profiles.

\section{Phage types of PVL-producing strains}

As shown in table III, 10 phage types were obtained with the 58 PVL-producing strains. Most of the strains were non-typable (39\%), or were in two types of phage group II $(47 \%)$. From the strains isolated from the eight patients with recurrent furuncles, four different phage susceptibility patterns were identified. These isolates were identical whether or not they originated from the anterior nares or from furuncles of the same patient. The isolates from the two patients belonging to the same family had the same phage type $(3 \mathrm{C} / 55)$.

\section{Genetic toxinotyping of PVL-producing strains}

The $l u k$ S-PV and $l u k$ F-PV probes hybridised with a single EcoRI DNA fragment whose size varied from $8.0 \mathrm{~kb}$ to $c .11 \mathrm{~kb}$, according to the strains. Among the 58 strains tested, there were at least five easily differentiated sizes of EcoRI DNA fragments that hybridised with the probes (fig. 1c), accounting for at least five genotypes. The hybridised DNA fragments corresponding to the isolates from the eight patients with recurrent furuncles were distributed into three sizes, $8 \cdot 0,8 \cdot 5$ and $c .9 \cdot 3 \mathrm{~kb}$ (data not shown). These genotypes were always identical among all isolates obtained from each of the eight patients with recurrent furuncles, and among the two patients belonging to the same family.

\section{PFGE pattern}

DNA from the 58 PVL-producing strains was analysed after SmaI endonuclease digestion and 18 different PFGE patterns were identified (fig. 2). They showed wide variability, accounting for the polymorphism of PVL-producing strains. Since the most frequently encountered pattern was observed for only four clinically distinct strains, a predominant pattern for DNA from PVL-producing strains could not be defined. It should be noted that the PFGE pattern of the reference PVL-producing strain ATCC 49775 was not found amongst the 18 different PFGE profiles mentioned above.

As a second stage, the PFGE patterns of DNA from the 24 PVL-producing isolates obtained at various times and locations (anterior nares and furuncles) from the eight patients with recurrent furuncles were studied. Five different PFGE patterns were observed with the PFGE profiles being identical in nasal and furuncle isolates of a given patient. For the two persons from the same family (patients $a_{1}$ and $a_{2}$ of fig. 3 ) suffering from furuncles, the isolates had the same PFGE-profile (lanes 4-7 and 8-9).

\section{Discussion}

Although PVL and $\gamma$-haemolysin were known as bi-component toxins, ${ }^{2,8,11,15}$ they remained poorly differentiated until their primary structures were reported. It now appears that both toxins, despite different biological activities, belong to the same protein family, the synergohymenotropic toxins of $S$. aureus. ${ }^{4}$ However, the PVL and $\gamma$-haemolysin genes are not equally distributed, since $\gamma$-haemolysin coding genes are constitutive in most $S$. aureus isolates, whereas PVL genes are rarely encountered.

DNA of $c .99 \%$ of clinical isolates hybridised with all three $\gamma$-haemolysin-specific oligonucleotide probes. In all 307 strains producing $\gamma$-haemolysin, the probes specific for $h l g \mathrm{~A}$ and $h l g \mathrm{C}$ recognised EcoRI DNA fragments of $>8.0 \mathrm{~kb}(c .11 \mathrm{~kb})$, while the $h l g \mathrm{~B}$ probe recognised $E c o$ RI DNA fragments of $c .4 \cdot 0 \mathrm{~kb}$. This result is in accordance with the EcoRI restriction maps of the $h l g$ loci already sequenced in three different strains $^{4,5,14,16}$ where there is always one EcoRI restriction site within the $h l g \mathrm{C}$ gene. This site is located between the hybridisation targets of $h l g \mathrm{C}$ and $h l g \mathrm{~B}$ probes. In these three sequenced $h l g$ loci, there is no $E c o$ RI restriction site between the targets of $h l g \mathrm{~A}$ and $h l g \mathrm{C}$ probes. Therefore, these two latter probes hybridise with an unique fragment with a size of $c .11 \mathrm{~kb}$, as determined by Southern blotting with strains Smith 5R ${ }^{16}$ and P83. ${ }^{5}$ In all 307 strains with $\gamma$-haemolysinencoding genes, the nucleotide sequences were not known, but $h l g \mathrm{~A}$ and $h l g \mathrm{C}$ probes always hybridised with an EcoRI fragment of $c$. $11 \mathrm{~kb}$. This suggests that in each of all these 307 strains too, $h l g \mathrm{~A}$ and $h l g \mathrm{C}$ genes belong to the same $11-\mathrm{kb} E c o \mathrm{RI}$ fragment and that $h l g \mathrm{~A}$ is always located in the vicinity of the cotranscribed $h l g \mathrm{C}$ and $h l g \mathrm{~B}$ open reading frames, as was observed in the three previously sequenced $h l g$ loci. Thus, it appears that the organisation of the $\gamma$ haemolysin locus is highly conserved in $S$. aureus strains.

The high frequency of $h l g$ genes and $\gamma$-haemolysin expression in $S$. aureus, suggests that this toxin (and its variants) might be relevant to the pathogenicity of $S$. aureus. If such an hypothesis is true, the rare isolates that do not produce any synergohymenotropic toxin should be considered as less pathogenic, or even as 
commensals; indeed, this was observed with the only two non-toxigenic strains detected so far.

In contrast to the high frequency of $\gamma$-haemolysin coding genes, PVL coding genes are less frequently distributed since they are encountered in only $2 \%$ of randomly obtained isolates. Five isolates from the preliminary survey produced PVL, three of which originated from primary cutaneous necrotic lesions.

Another interesting result obtained in this study concerned the PVL-producing strains: five such isolates obtained in the preliminary survey as well as all the 75 other clinical isolates obtained from blood and skin infections, harboured not only the two genes coding for PVL, but also the three genes encoding $\gamma$ haemolysin. HlgB and F components are known to have structural homologies and can be classified as components of class $\mathrm{F}$; $\mathrm{HlgA}, \mathrm{HlgC}$ and $\mathrm{S}$ components also have structural homologies and, therefore, can be classified as components of class $\mathrm{S}$. If all five proteins are produced in vivo, as they are in vitro, ${ }^{4}$ in PVLproducing strains, the association of a given protein of class $S$ with a given protein of class $F$ could generate six $(\mathrm{F}+\mathrm{S})$ molecular combinations produced by all PVL-producing strains. The biological activity of all these pairings remains to be investigated. In contrast, for the strains producing only $\gamma$-haemolysin, two toxic combinations only are possible: $\mathrm{HlgA} / \mathrm{HlgB}$ and $\mathrm{HlgC} / \mathrm{HlgB}$.

PVL and $\gamma$-haemolysin are known to be structurally and functionally different and the prospective epidemiological study strengthened this difference. PVL-producing strains were not associated with bacteraemia in the preliminary study (table I) or in the prospective survey (table II). However, such strains were associated mostly with primary cutaneous infections, and especially with furuncles. These PVLproducing isolates were found in almost all furuncles

\section{References}

1. Woodin AM. The staphylococcal leukocidin. In: Cohen JO (ed) The staphylococci. New York, Wiley Interscience. 1972: 281-289.

2. Guyonnet F, Plommet M. Hémolysine gamma de Staphylococcus aureus: purification et propriétés. Ann Inst Pasteur $1970 ; 118$ : 19-33.

3. Taylor AG, Bernheimer AW. Further characterization of staphylococcal gamma-hemolysin. Infect Immun 1974; 10: 54-59.

4. Prevost G, Supersac G, Colin DA et al. The new family of leucotoxins from Staphylococcus aureus: structural and biological properties. In: Freer et al. (eds) Bacterial protein toxins. Zentralbl Bakteriol Suppl 24, Gustav Fischer Verlag, Stuttgart, Jena, New York. 1994: 284-293.

5. Supersac G, Prevost G, Piemont Y. Sequencing of leucocidin R from Staphylococcus aureus P83 suggests that staphylococcal leucocidins and gamma-hemolysin are members of a single, two-component family of toxin. Infect Immun $1993 ; 61: 580-587$.

6. Gladstone GP, Van Heyningen WE. Staphylococcal leucocidins. Br J Exp Pathol 1957; 38: 123-137.

7. Panton PN, Valentine FCO. Staphylococcal toxin. Lancet 1932; 1: : 506-508.

8. Finck-Barbançon V, Prevost G, Piemont Y. Improved purification of leukocidin from Staphylococcus aureus and toxin distribution among hospital strains. Res Microbiol $1991 ; 142$ : 75-85. and also in the anterior nares from all patients so far examined who had recurrent furuncles. A looser association was also observed with abscesses and whitlows. The ability to produce PVL could be at least considered as a good marker of the capability of a $S$. aureus strain to cause necrotising skin lesions. The strains were observed to be generally susceptible to most antibiotics having variable phenotypes for penicillin, doxycycline and erythromycin. PFGE profiles and lysotypes of PVL-positive $S$. aureus strains provided more polymorphic markers than toxin genotypes on DNA treated with EcoRI.

Recurrent furunculosis and small familial outbreaks of furuncles are sometimes observed and are difficult to cure. It is of particular interest to notice that amongst PVL-producing isolates from individuals belonging to the same family, the same epidemiological marker pattern was obtained. Moreover, in eight patients with recurrent furuncles, PVL-producing isolates were always obtained from the nose, and powerful epidemiological markers such as phage typing and PFGE analysis failed to distinguish between nose and furuncle strains. This finding may be important in the epidemiology of furuncles since nasal carriage was previously recognised as a constant feature in recurrent furunculosis. ${ }^{23}$ Therefore, epidemiological markers, including phenotypic toxinotyping (production of PVL) associated with PFGE typing, will be useful for identifying the reservoir of $S$. aureus between episodes of furunculosis. Therapeutic regimens specifically directed to this reservoir could be evaluated in an attempt to prevent these infections.

The technical assistance of C. Fritsch and D. Keller was greatly appreciated. This work was supported by grants from the "Fondation pour la Recherche Médicale" and from the Institut National pour la Santé et la Recherche Médicale (INSERM: CRE No.900316).

9. Woodin AM. Purification of the two components of leucocidin from Staphylococcus aureus. Biochem J 1960; 75: 158-165.

10. Soboll H, Ito A, Schaeg W, Blobel H. Leukozidin von Staphylokokken Verscheidener Herkunft. Zentralbl Bakteriol Orig A 1973; 224: 184-193.

11. Kamio Y, Rahman A, Nariya H, Ozawa T, Izaki $\mathrm{K}$. The two staphylococcal bi-component toxins, leukocidin and gamma-hemolysin, share one component in common. FEBS Lett 1993; 321 : 15-18.

12. Noda M, Hirayama T, Kato I, Matsuda F. Crystallization and properties of staphylococcal leukocidin. Biochem Biophys Acta 1980; 633: 33-44.

13. Rahman A, Nariya H, Izaki K, Kato I, Kamio Y. Molecular cloning and nucleotide sequence of leukocidin Fcomponent gene (lukF) from methicillin resistant Staphylococcus aureus. Biochem Biophys Res Commun 1992; 184: 640-646.

14. Rahman A, Izaki K, Kamio Y. Gamma-hemolysin genes in the same family with $l u k \mathrm{~F}$ and $l u k \mathrm{~S}$ genes in methicillin resistant Staphylococcus aureus. Biosci Biotech Biochem 1993; 57: 1234-1236.

15. Clyne M, Birbeck TH, Arbuthnott JP. Characterization of staphylococcal gamma-lysin. J Gen Microbiol 1992; 138: 923-930.

16. Cooney J, Kienle Z, Foster TJ, O'Toole PW. The gammahemolysin locus of Staphylococcus aureus comprises three linked genes, two of which are identical to the genes for $\mathrm{F}$ and S components of leucocidin. Infect Immun 1993; 61: 768-771. 
17. Cribier B, Prévost G, Couppié P, Finck-Barbançon V, Grosshans E, Piémont Y. Staphylococcus aureus leucocidin: a new virulence factor in cutaneous infections? An epidemiological and experimental study. Dermatology 1992; 185: 175-180.

18. Ward PD, Turner WH. Identification of staphylococcal PantonValentine leukocidin as a potent dermonecrotic toxin. Infect Immun 1980; 28: 393-397.

19. Sambrook J, Fritsch EF, Maniatis T (eds). Molecular cloning: a laboratory manual, 2nd edn. Cold Spring Harbor, New York, Cold Spring Harbor Laboratory Press. 1989.

20. Southern EM. Detection of specific sequence among DNA fragments separated by gel electrophoresis. $J \mathrm{Mol}$ Biol 1975; 98: 503-517.

21. Blair JE, Williams REO. Phage typing of staphylococci. Bull WHO 1961; 24: 771-784.

22. Prevost G, Jaulhac B, Piemont Y. DNA fingerprinting by pulsed-field gel electrophoresis is more effective than ribotyping in distinguishing among methicillin-resistant Staphylococcus aureus isolates. J Clin Microbiol 1992; 30 : 967-973.

23. Hedström SÅ. Recurrent furonculosis. Bacteriological findings and epidemiology in 100 cases. Scand J Infect Dis 1981; 13: 115-119. 